\title{
Hydroxycarboxylic acid receptors are essential for breast cancer cells to control their lipid/fatty acid metabolism
}

\author{
Claudia Stäubert ${ }^{1,2,3}$, Oliver Jay Broom² and Anders Nordström ${ }^{1,2}$ \\ 1 Swedish Metabolomics Centre, Department of Forest Genetics and Plant Physiology, Swedish University of Agricultural \\ Sciences, Umeå, Sweden \\ 2 Department of Molecular Biology, Umeå University, Umeå, Sweden \\ ${ }^{3}$ Institute of Biochemistry, Faculty of Medicine, University of Leipzig, Leipzig, Germany \\ Correspondence to: Claudia Stäubert, email: claudia.staubert@molbiol.umu.se \\ Anders Nordström, email: anders.nordstrom@molbiol.umu.se
}

Keywords: hydroxycarboxylic acid receptors, cancer metabolism, metabolite-sensing GPCRs, GPR81, GPR109a

Received: August 28, 2014

Accepted: February 26, 2015

Published: March 14, 2015

This is an open-access article distributed under the terms of the Creative Commons Attribution License, which permits unrestricted use, distribution, and reproduction in any medium, provided the original author and source are credited.

\section{ABSTRACT}

Cancer cells exhibit characteristic changes in their metabolism with efforts being made to address them therapeutically. However, targeting metabolic enzymes as such is a major challenge due to their essentiality for normal proliferating cells. The most successful pharmaceutical targets are G protein-coupled receptors (GPCRs), with more than $40 \%$ of all currently available drugs acting through them.

We show that, a family of metabolite-sensing GPCRs, the Hydroxycarboxylic acid receptor family (HCAs), is crucial for breast cancer cells to control their metabolism and proliferation.

We found $\mathrm{HCA}_{1}$ and $\mathrm{HCA}_{3}$ mRNA expression were significantly increased in breast cancer patient samples and detectable in primary human breast cancer patient cells. Furthermore, siRNA mediated knock-down of $\mathrm{HCA}_{3}$ induced considerable breast cancer cell death as did knock-down of HCA $_{1}$, although to a lesser extent. Liquid Chromatography Mass Spectrometry based analyses of breast cancer cell medium revealed a role for $\mathrm{HCA}_{3}$ in controlling intracellular lipid/fatty acid metabolism. The presence of etomoxir or perhexiline, both inhibitors of fatty acid $\beta$-oxidation rescues breast cancer cells with knocked-down $\mathrm{HCA}_{3}$ from cell death.

Our data encourages the development of drugs acting on cancer-specific metabolite-sensing GPCRs as novel anti-proliferative agents for cancer therapy.

\section{INTRODUCTION}

Ever since Warburg's discovery of aerobic glycolysis as a metabolic hallmark of cancer cells, extensive studies have increased our understanding of cancer cell metabolism [1, 2]. Characteristic metabolic changes, besides aerobic glycolysis have been identified including, increased lactate production, glutamine metabolism, and fatty acid synthesis, coupled with decreased fatty acid oxidation [1,2]. Cancer-specific up-regulated enzymes involved in central metabolic pathways have been identified, and have come into focus as targets for cancer therapy [3-5]. However, because all cells depend on the same central metabolic pathways, one main obstacle is the toxicity of drugs acting upon those enzymes [3-5].

$\mathrm{G}$ protein-coupled receptors (GPCRs) constitute the largest family of transmembrane receptors, transduce diverse extracellular signals inside the cell and represent one of the major pharmaceutical targets [6, 7]. Recently, a growing number of so far orphan GPCRs, have been shown to be activated by metabolic intermediates or energy substrates [8]. The HCA family of receptors consists of three members that are mainly expressed in adipocytes $[9,10]$. Activation by their respective agonists inhibits adipocyte lipolysis $[9,10]$. $\mathrm{HCA}_{1}$ is activated by lactate, a product of glycolysis, the endogenous agonist for $\mathrm{HCA}_{2}$ is 3-hydroxybutyrate (3HB), a ketone body and for $\mathrm{HCA}_{3}, 3$-hydroxyoctanoate (3HO), an intermediate of 
fatty acid $\beta$-oxidation (FAO) (Figure 1) $[9,10]$.

Since HCAs are activated by intermediates of central metabolic processes that are often differentially regulated in cancer cells (e.g. glycolysis), we set out to investigate their potential role for cancer cell proliferation.

Here, we demonstrate that $\mathrm{HCA}_{1}$ and $\mathrm{HCA}_{3}$ mRNA expression is increased in human breast cancer patient tissue as compared to normal tissue samples, and in primary breast cancer cells. We provide evidence, that $\mathrm{HCA}_{3}$ and to a lesser extent $\mathrm{HCA}_{1}$, are essential for breast cancer cells to control their lipid/fatty acid metabolism. Cancer cell metabolism is perturbed when cellular transmembrane "metabolic surveillance", through namely $\mathrm{HCA}_{1}$ and $\mathrm{HCA}_{3}$, is abrogated causing a decrease in viability and/or cell death. Thus, $\mathrm{HCA}_{1}$ and $\mathrm{HCA}_{3}$ constitute potential targets for therapeutic intervention in cancer.

\section{RESULTS}

\section{Breast cancer patient tissue exhibits higher HCA mRNA expression levels when compared to normal breast tissue}

Since a relevance of HCAs for cancer cell metabolism can only be assumed if they are expressed in human cancer patient tissue, we first analyzed the
mRNA expression levels of $\mathrm{HCA}_{1}, \mathrm{HCA}_{2}$ and $\mathrm{HCA}_{3}$ in eight different cancers versus the respective normal tissues. For this purpose we used the Cancer and Normal TissueScan $^{\mathrm{TM}}$ Cancer Survey cDNA qPCR Array - I (CSRT501) (Origene) which contains tissue cDNAs that are synthesized from high quality total RNAs of pathologist-verified tissues, normalized and validated with $\beta$-actin in two sequential qPCR analyses, and are provided with clinical information and QC data. $\mathrm{HCA}_{2}$ and $\mathrm{HCA}_{3}$ mRNA expression was significantly higher in colon cancer and $\mathrm{HCA}_{2}$ was lower in kidney, slightly lower in lung and slightly increased in ovarian cancer samples (Figure S1). However, the strongest differential mRNA expression of $\mathrm{HCA}_{1}$ (Figure 2A), $\mathrm{HCA}_{2}$ (Figure 2B) and $\mathrm{HCA}_{3}$ (Figure $2 \mathrm{C}$ ) was detected in breast cancer patient versus normal tissue samples, with $\mathrm{HCA}_{1}$ showing about 5-fold, $\mathrm{HCA}_{2}$ about 2-fold and $\mathrm{HCA}_{3}$ about 3-fold higher mRNA expression levels (Figure 2A-C).

\section{$\mathrm{HCA}_{1}$ and $\mathrm{HCA}_{3}$ transcripts are expressed in primary breast cancer cells}

Following these results, we obtained primary breast cancer cells from three different patients and analyzed HCA mRNA expression. We found $\mathrm{HCA}_{1}$ mRNA expression more than 100-fold (Figure 2D), $\mathrm{HCA}_{2}$ mRNA expression unchanged (Figure 2E) and $\mathrm{HCA}_{3}$ mRNA expression about 50-fold higher (Figure 2F) in

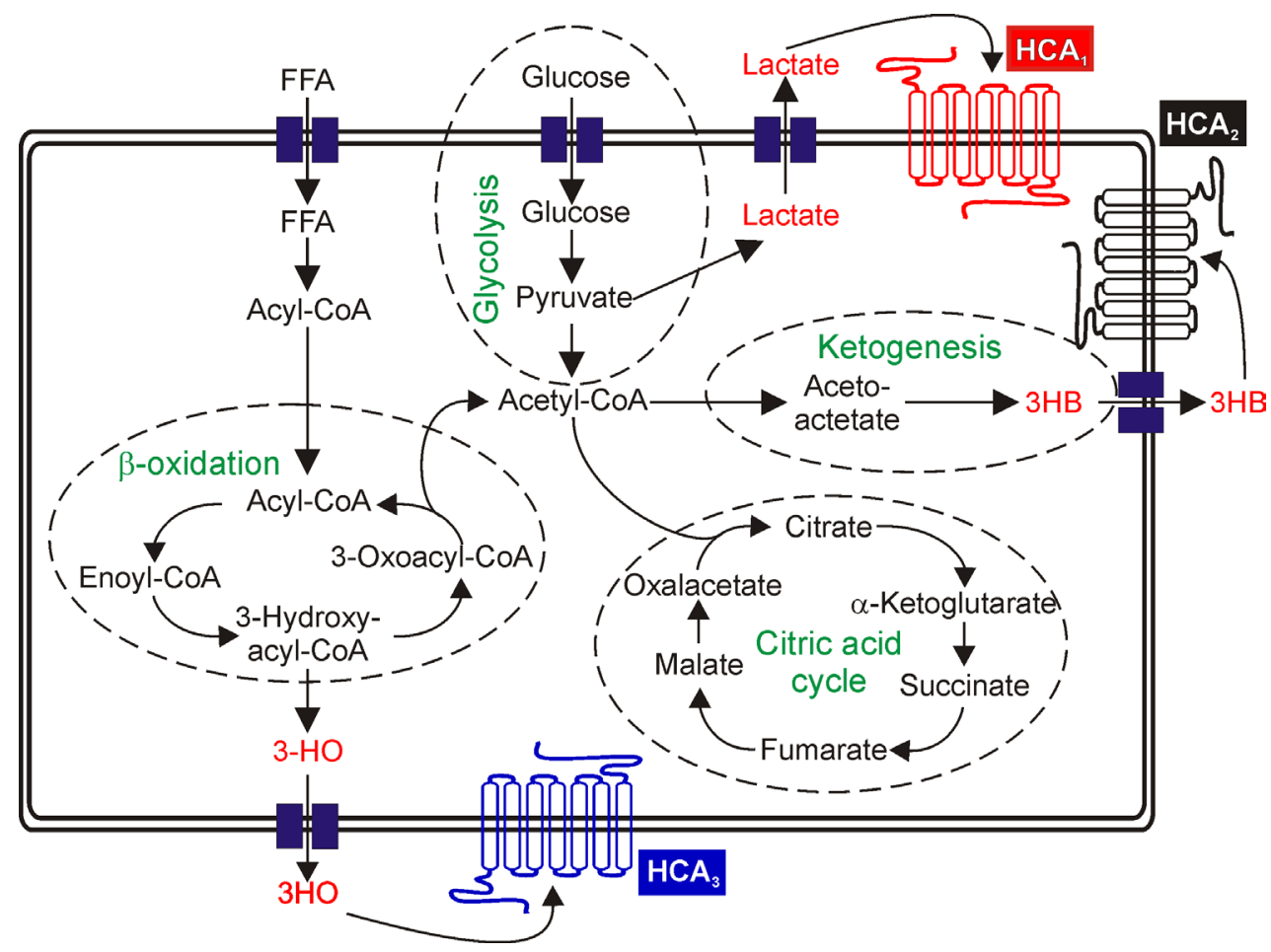

Figure 1: Schematic overview of HCA agonist generating metabolic pathways. Lactate, the endogenous agonist of $\mathrm{HCA}_{1}$, is an indicator for increased rates of glycolysis. Excess acetyl-CoA is converted to ketone bodies, one of which is $3 \mathrm{HB}$ - the endogenous agonist of $\mathrm{HCA}_{2}$ and $3 \mathrm{HO}$, agonist of $\mathrm{HCA}_{3}$ is an intermediate of FAO. FFA: free fatty acid. 
A
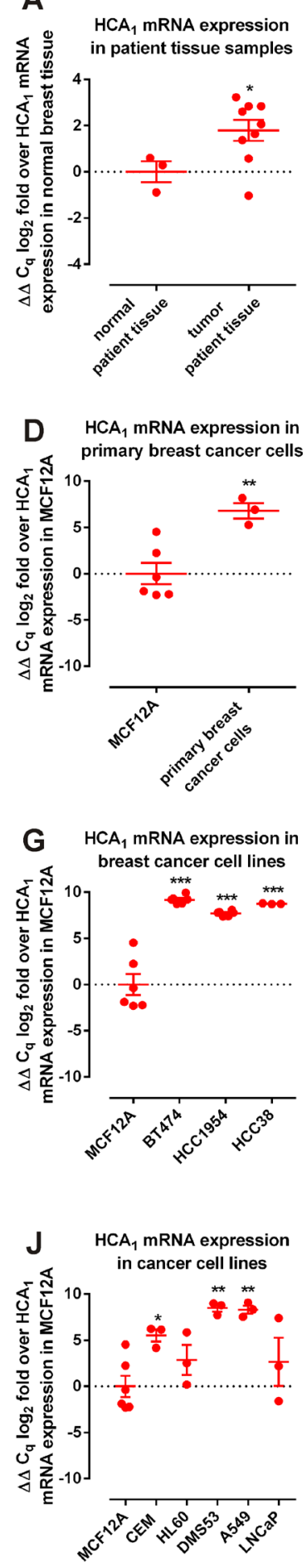
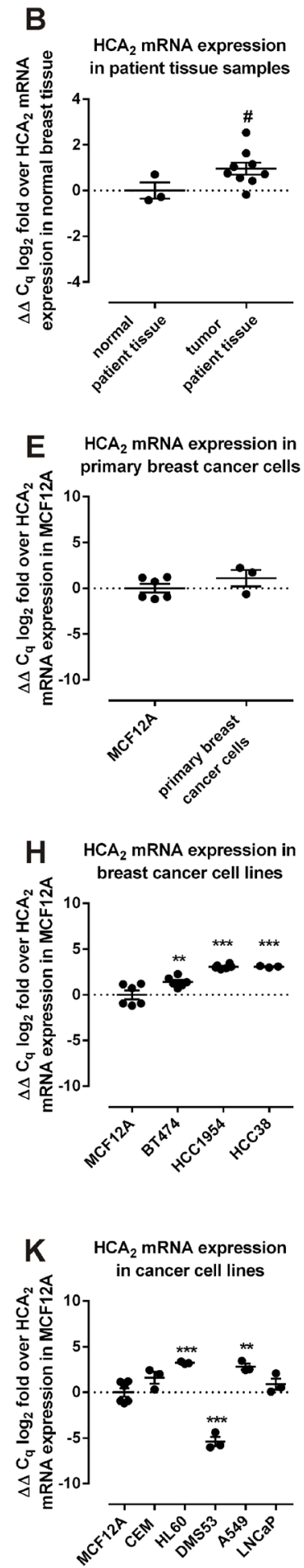
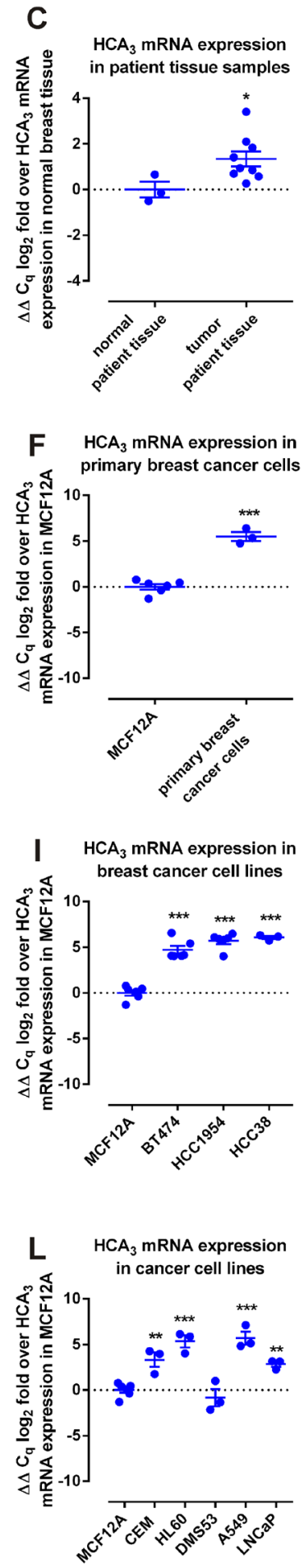

Figure 2: HCAs are overexpressed in human patient breast cancer tissue, primary breast cancer cells and breast cancer cell lines. (A-C) Expression of HCAs in breast cancer $(n=9)$ versus normal $(n=3)$ patient tissue (two-tailed unpaired t-test, Welch's correction). (D-F) Expression of HCAs in primary human breast cancer cells $(\mathrm{n}=3)$ versus non-tumorigenic epithelia breast cells MCF12A (two-tailed unpaired t-test, Welch's correction). (G-I) HCA expression in breast cancer cells BT-474, HCC1954 and HCC38 versus non-tumorigenic epithelia breast cells MCF12A ( $n=6$ for all except for HCC38 $n=3$, ordinary One-Way ANOVA, Dunnett's multiple comparisons test). (J-L) mRNA expression of HCA in two leukemia cell lines (CEM, HL60), two lung cancer cell lines (DMS53, A549) and one prostate cancer cell line (LNCaP) versus non-tumorigenic epithelia breast cells MCF12A ( $n=3$ except for MCF12A $n=6$, ordinary One-Way ANOVA, Dunnett's multiple comparisons test). Data is shown as mean $\pm \mathrm{SEM}$. ${ }^{*} \mathrm{P} \leq 0.1 * \mathrm{P} \leq 0.05 ; * * \mathrm{P} \leq 0.01 ; * * * \mathrm{P}$ $\leq 0.001$. 
the primary breast cancer cells when compared to HCA mRNA expression in the non-tumorigenic epithelial breast cell line MCF12A.

\section{Higher HCA mRNA expression in breast cancer cell lines}

Next, we set out to analyze the HCA mRNA expression in the breast cancer cell lines BT-474 (progesterone receptor (PR) positive, estrogen receptor (ER) positive, HER2/neu positive), HCC1954 (PR negative, ER negative, HER2/neu positive) and HCC38 (PR negative, ER negative, HER2/neu negative) versus the non-tumorigenic epithelial breast cell line MCF12A. Compared to MCF12A, the mRNA levels of all three HCAs were significantly higher in all three breast cancer cell lines (Figure 2G-I).

\section{HCA mRNA expression in other cancer cell lines}

We further assessed HCA mRNA expression in two leukemia, two lung cancer and one prostate cancer cell lines relative to HCA expression in MCF12A (Figure 2J-L). HCA 1 mRNA expression was significantly higher in the lung cancer cell lines A549 and DMS53 as well as in the acute lymphoblastic leukemia cell line CEM (Figure 2J). Expression of $\mathrm{HCA}_{2}$ transcripts was found significantly higher in the acute promyelocytic leukemia cell line HL60 and the lung cancer cell line A549, whereas expression in DMS53 cells was lower when compared to $\mathrm{HCA}_{2}$ mRNA expression in MCF12A cells (Figure 2K). All cancer cell lines except DMS53 showed an increased $\mathrm{HCA}_{3}$ mRNA expression (Figure 2L). Presence of $\mathrm{HCA}_{2}$ and $\mathrm{HCA}_{3}$ mRNA transcripts has been demonstrated before in LoVo colorectal adenocarcinoma cells [11].

\section{Comparison of HCA mRNA expression levels in normal tissue relative to expression in breast}

In Table $\mathrm{S} 1$ we provide the information given by Origene for all normal tissue samples included in the Cancer and Normal TissueScan ${ }^{\mathrm{TM}}$ Cancer Survey cDNA qPCR Array - I (CSRT501) (Origene). Analyzing these samples using RT-qPCR we found highest $\mathrm{HCA}_{1}$ mRNA in breast tissue (Figure S2A). No $\mathrm{HCA}_{1}$ expression
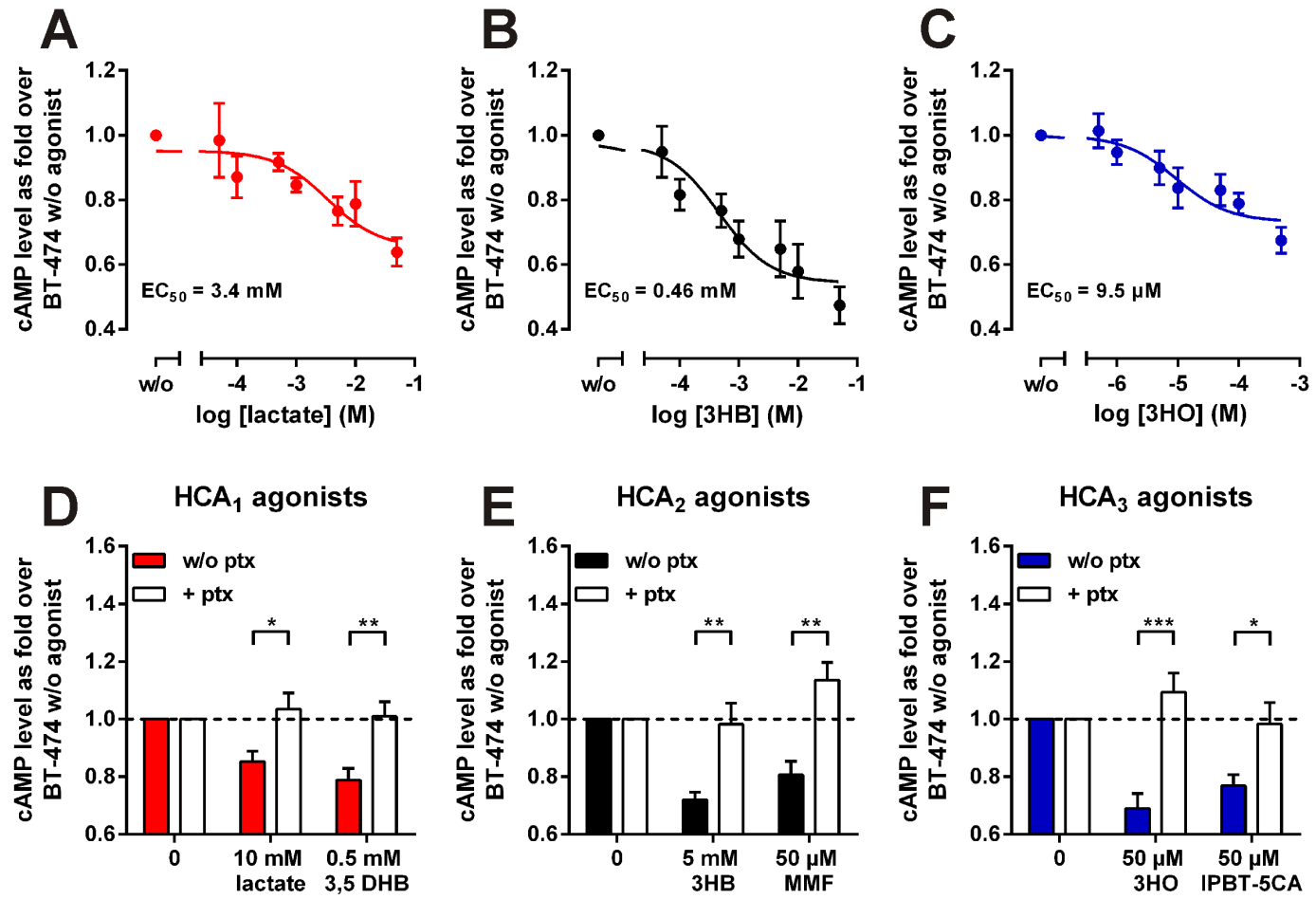

Figure 3: Lactate, 3-hydroxybutyrate (3HB) and 3-hydroxyoctanoate (3HO) activate endogenous HCA receptors in BT-474 cells in a pertussis toxin sensitive manner. (A-C) HCA agonist-mediated inhibition of forskolin-induced cAMP production in BT-474 cells was determined using the AlphaScreen ${ }^{\circledR}$ cAMP Assay Kit. The cyclic AMP level of cells stimulated with $10 \mu \mathrm{M}$ forskolin in absence of agonist was set $1 . \mathrm{EC}_{50}$ values were determined from concentration-response curves of agonists using GraphPad Prism $(\mathrm{n}=$ 3). (D-F) Agonist-induced decrease in intracellular cAMP levels is pertussis toxin sensitive $(n=4) .3,5$ DHB: 3,5-dihydroxybenzoic acid, MMF: mono-methyl fumarate, IPBT-5CA (IBC-293): 1-(1-Methylethyl)-1H-benzotriazole-5-carboxylic acid. All data is shown as mean \pm SEM. p-values were determined using a two-tailed unpaired t-test. * $\mathrm{P} \leq 0.05 ; * * \mathrm{P} \leq 0.01 ; * * * \mathrm{P} \leq 0.001$ 
was detectable in normal colon, kidney and liver tissue samples. $\mathrm{HCA}_{2}$ mRNA expression could be shown for all normal tissue samples with highest level of expression in kidney and liver (Figure S2B). Transcripts of $\mathrm{HCA}_{3}$ were also detectable in all normal tissue samples with highest expression in kidney, liver and lung (Figure S2C).

\section{HCA mRNA expression levels relative to $\mathrm{HCA}_{1}$ in cancer cell lines}

Moreover, we analyzed our RT-qPCR data obtained from all 9 cell lines regarding the expression of $\mathrm{HCA}_{2}$ and $\mathrm{HCA}_{3}$ relative to $\mathrm{HCA}_{1}$ to provide information about the relative abundance of $\mathrm{HCA}$ transcripts in comparison to each other. In MCF12A, (Figure S2D), HCC1954 (Figure S2F), HL60 (Figure S2I) and LNCaP cells $\mathrm{HCA}_{2}$ and $\mathrm{HCA}_{3}$ transcripts are more abundant than $\mathrm{HCA}_{1}$ transcripts. The opposite is true for BT-474 (Figure S2E) and DMS53 (Figure S2J) cells and no difference in HCA transcript abundance is found in HCC38 (Figure S2G), CEM (Figure S2H) and A549 (Figure S2K) cells.

\section{HCA agonist stimulation induces a decrease in intracellular cAMP levels in BT-474}

All members of the HCA receptor family are $\mathrm{G} \alpha_{i}$ coupled receptors [10]. Thus, agonist-mediated receptor activation induces inhibition of adenylyl cyclase and the intracellular cAMP level is subsequently reduced. We performed cAMP assays in the presence of $10 \mu \mathrm{M}$ forskolin and increasing concentrations of lactate, $3 \mathrm{HB}$ or $3 \mathrm{HO}$ in BT-474 (Figure 3A-B). Thereby we were able to determine an $\mathrm{EC}_{50}$ of $3.4 \mathrm{mM}$ for lactate, $0.46 \mathrm{mM}$ for $3 \mathrm{HB}$ and $9.5 \mu \mathrm{M}$ for $3 \mathrm{HO}$ (Figure 1D-F). Lactate has been reported to activate human $\mathrm{HCA}_{1}$ with an $\mathrm{EC}_{50}$ in the range of 1.3 - $5 \mathrm{mM}$ [12-14]. The $\mathrm{EC}_{50}$ value of $3 \mathrm{HB}$ activating $\mathrm{HCA}_{2}$ has been reported as $0.7 \mathrm{mM}$ [15] and of $3 \mathrm{HO}$ activating $\mathrm{HCA}_{3}$ as $8 \mu \mathrm{M}$ [16]. Accordingly, our data strongly suggests the presence of functional $\mathrm{HCA}_{1}$, $\mathrm{HCA}_{2}$ and $\mathrm{HCA}_{3}$ receptor protein in BT-474 cells. To exclude that the inhibitory effects on cAMP levels exerted by lactate, $3 \mathrm{HB}$ and $3 \mathrm{HO}$ are unspecific effects of high metabolite concentrations, we tested their sensitivity to pertussis toxin. Pertussis toxin is an inhibitor of the $\mathrm{G} \alpha$. protein and blocked both endogenous (lactate, $3 \mathrm{HB}$ and $3 \mathrm{HO}$ ) and synthetic HCA agonist-induced decrease in intracellular cAMP levels in BT-474 cells (Figure 3DF). 3,5 dihydroxybenzoic acid is a specific $\mathrm{HCA}_{1}$ agonist [17], $\mathrm{HCA}_{2}$ is known to be activated by the antipsoriatic drug monomethyl fumarate [18] and IPBT-5CA (IBC-293, 1-(1-methylethyl)-1H-benzotriazole-5-carboxylic acid) is a selective $\mathrm{HCA}_{3}$ agonist $[19,20]$.
siRNA directed against $\mathrm{HCA}_{1}$ and $\mathrm{HCA}_{3}$ decreases the viability of breast cancer cell lines but not of MCF12A and HEK293T

To assess whether the HCAs are essential for breast cancer cell line proliferation we performed siRNAmediated knock-down experiments. Microscopy images of crystal violet-stained cells revealed that knock-down of $\mathrm{HCA}_{1}$ slightly and of $\mathrm{HCA}_{3}$ considerably, decreased viability in both BT-474 and HCC1954 whereas no effect was observed for MCF12A and HEK293T cells (Figure $4 \mathrm{~A}$ ). These qualitative results were further confirmed by quantification of cell viability through measurement of the relative ATP level. The knock-down efficiency as well as the co-regulation of related HCA mRNA expression, was monitored using reverse-transcriptase quantitative PCR (RT-qPCR).

For all experiments, we used pooled siRNA containing one third of each A, B and C siRNA provided from OriGene (Table S2). However, we also measured the viability of BT-474 and HCC1954 cells upon the transfection of each individual siRNA. Thereby, we were able to detect a significant decrease in viability of both cell lines $72 \mathrm{~h}$ after transfection with siHCA $-\mathrm{A}_{1}$ and $\mathrm{siHCA}_{1}-\mathrm{C}$, or with $\mathrm{siHCA}_{3}-\mathrm{B}$ and $\mathrm{siHCA}_{3}-\mathrm{C}$ (Figure $\mathrm{S} 3$ ).

An $80 \%$ knock-down of $\mathrm{HCA}_{1}$ (Figure S4A) caused a $20 \%$ and $40 \%$ decrease in HCC 1954 viability after $48 \mathrm{~h}$ and $72 \mathrm{~h}$, respectively, whereas it had no significant influence on BT-474 viability (Figure 4B). HCA knockdown was accompanied by an increased mRNA expression of $\mathrm{HCA}_{2}$ and $\mathrm{HCA}_{3}$ (Figure S4A). 48h after siHCA transfection $\mathrm{HCC} 38$ viability was already about $60 \%$ reduced. But, $72 \mathrm{~h}$ after transfection with siHCA $\mathrm{A}_{1}$ no effect on viability was observed for cells that do not express $\mathrm{HCA}_{1}$, specifically MCF12A and HEK293T (Figure 4B).

In contrast, the viability of BT-474 cells exhibiting a $60-70 \%$ knock-down of $\mathrm{HCA}_{2}$ (Figure S4B) was significantly increased, had no effect on HCC1954, MCF12A and HEK293T viability and induced a significant reduction in viability in $\mathrm{HCC} 38$ cells (Figure 4C).

The cell viability of the BT-474 cells was $40 \%$, $80 \%$ and $90 \%$ reduced $24 \mathrm{~h}, 48 \mathrm{~h}$ and $72 \mathrm{~h}$ after siHCA transfection, and for the HCC1954 cells, 50\% and 80\% after $48 \mathrm{~h}$ and $72 \mathrm{~h}$, respectively (Figure 4D). The viability of the siHCA ${ }_{3}$ transfected HCC38 cells was already after $24 \mathrm{~h} 60 \%$ lower when compared to siNC transfected HCC 38 cells and only $10-20 \%$ of cells were still alive after $48 \mathrm{~h}$ and $72 \mathrm{~h}$ (Figure 4D).

The $\mathrm{HCA}_{3}$ knock-down could not reliably be determined when experiments were carried out in presence of $2.5 \%$ fetal bovine serum (FBS) which was used to ensure high transfection efficiency (Figure S4C). The knock-down of $\mathrm{HCA}_{3}$ in breast cancer cells causes induction of apoptosis in those cells (Figure 5C) which in turn leads to changes in reference gene expression, 

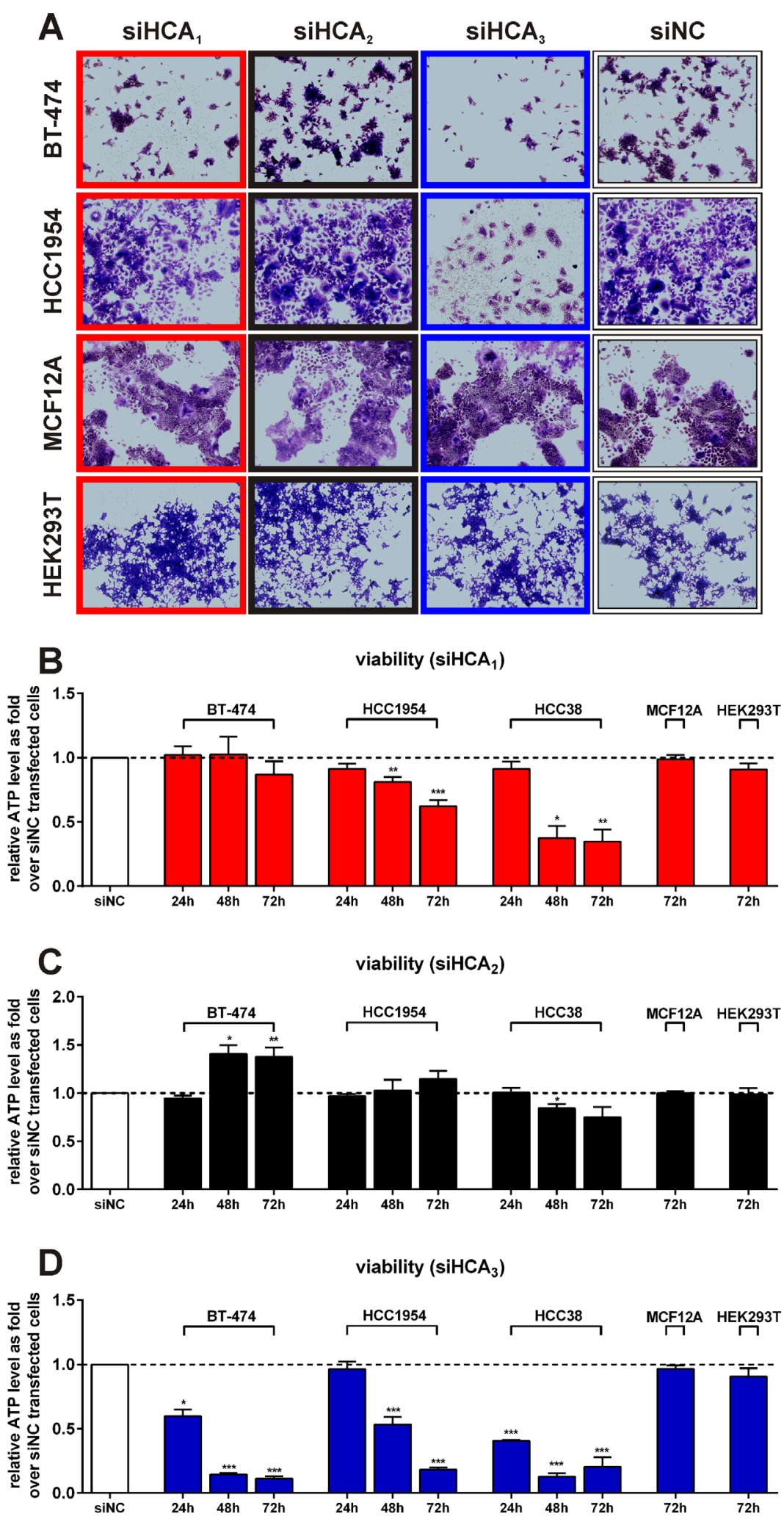

Figure 4: Effect of $\mathrm{HCA}_{1}, \mathrm{HCA}_{2}$ and $\mathrm{HCA}_{3}$ siRNA mediated knock-down on BT-474, HCC1954, HCC38, MCF12A and HEK293T cell viability. (A) Crystal violet staining of BT-474, HCC1954 MCF12A and HEK293T cells transfected with siRNA directed against $\mathrm{HCA}_{1}, \mathrm{HCA}_{2}$ and $\mathrm{HCA}_{3}$ versus scrambled negative control (siNC) after $48 \mathrm{~h}$. Cell viability of siHCA 1 (B), siHCA $(\mathrm{C})$ and siHCA $($ D) versus siNC transfected BT-474, HCC1954 (both: 24h: $\mathrm{n}=3,48 \mathrm{~h}: \mathrm{n}=4,72 \mathrm{~h}: \mathrm{n}=6$ ), HCC38 (24h, 48h, 72h: each $\mathrm{n}=3$ ) MCF12A and HEK293T (both 72h: $\mathrm{n}=3$ ) cells. All data is shown as mean \pm SEM. $\mathrm{p}$-values were determined using a two-tailed unpaired t-test. * $\mathrm{P} \leq 0.05 ; * * \mathrm{P} \leq 0.01 ; * * * \mathrm{P} \leq 0.001$. 
thus preventing the reliable determination of $\Delta \Delta C_{q}$. However, with serial reduction of $\mathrm{HCA}_{3}$ specific siRNA and performing the experiments in the presence of $10 \%$ FBS, transfection efficiency was decreased and viability less effected (Figure S5A-D) thereby allowing detection of $30-40 \%$ and $20-70 \%$ siHCA $_{3}$-mediated decrease in $\mathrm{HCA}_{3}$ mRNA levels in BT-474 and HCC1954, respectively (Figure S5E-F). Further, we assessed HCA cell surface expression in transiently HCA overexpressing HEK293T cells co-transfected with either respective HCA-specific siRNA or siNC using an indirect cellular ELISA (Figure S6A-C). 24h after co-transfection with HA-tagged HCA-encoding plasmid and siRNA we could detect an approximate $50 \%$ decrease in HA-tagged $\mathrm{HCA}_{1}$ cell surface expression (Figure S6A), 40\% less HA-tagged $\mathrm{HCA}_{2}$ receptor on the cell surface (Figure S6B) and approximately $60 \%$ reduction of the $\mathrm{HA}$-tagged $\mathrm{HCA}_{3}$ cell surface expression in HEK293T cells (Figure S6C).
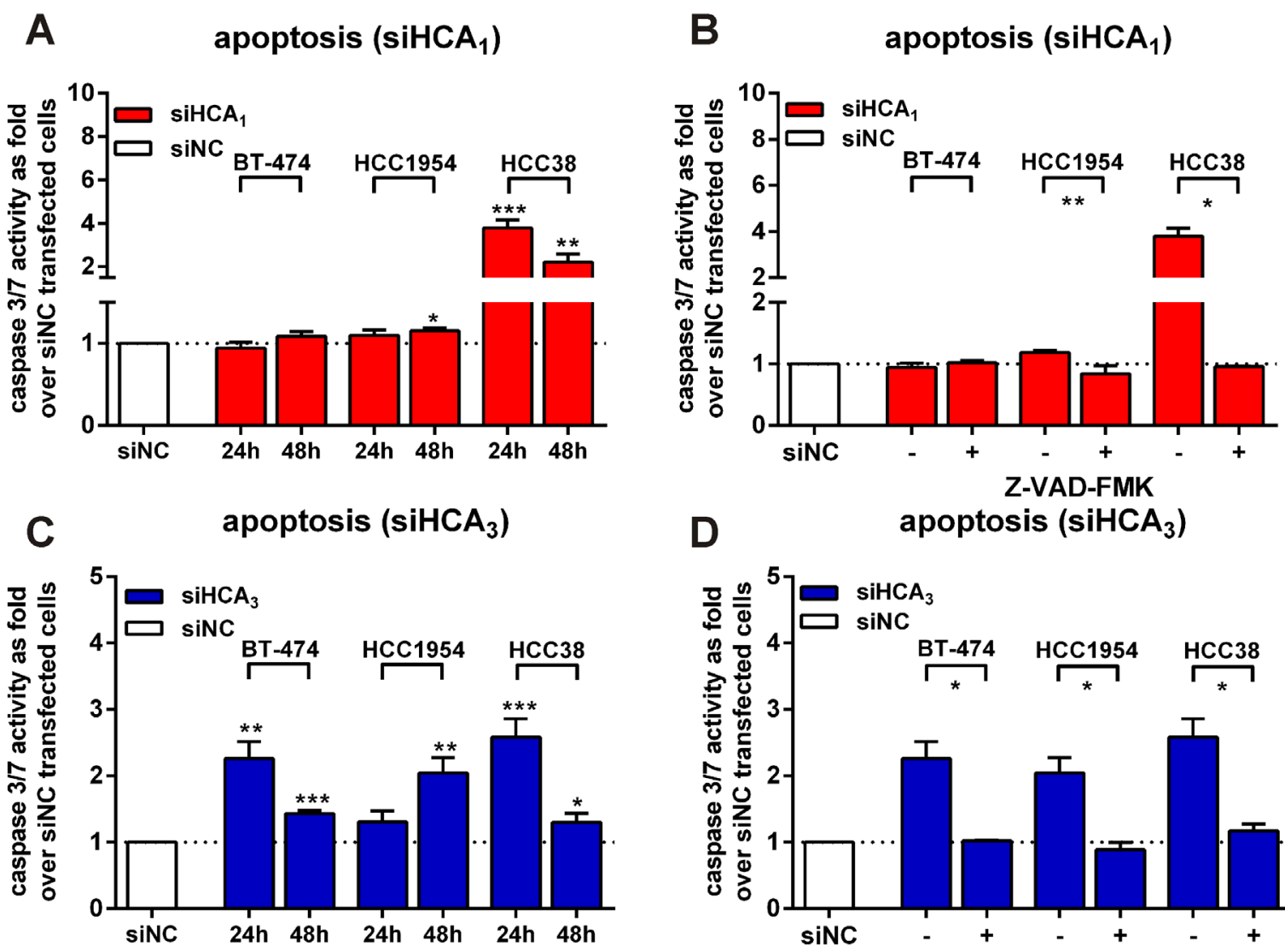

Transiently $\mathrm{HCA}_{1}$ and $\mathrm{HCA}_{3}$ overexpressing BT-474 and HCC1954 show increased viability when compared to mock-transfected cells

We next tested the influence of transient overexpression of $\mathrm{HCA}_{1}, \mathrm{HCA}_{2}$ and $\mathrm{HCA}_{3}$ on the BT-474 and HCC1954 cell viability. Transiently transfected, $\mathrm{HCA}_{1}$-overexpressing BT-474 and to lesser extent HCC1954 exhibited an increased cell viability when compared to cells transfected with empty vector (Figure S6D). The cell viability of $\mathrm{HCA}_{2}$ overexpressing HCC1954 was reduced after $72 \mathrm{~h}$ whereas no effect was observed in BT-474 cells (Figure S6E). An increased viability in transiently $\mathrm{HCA}_{3}$ overexpressing BT-474 and HCC1954 cells was observed (Figure S6F).

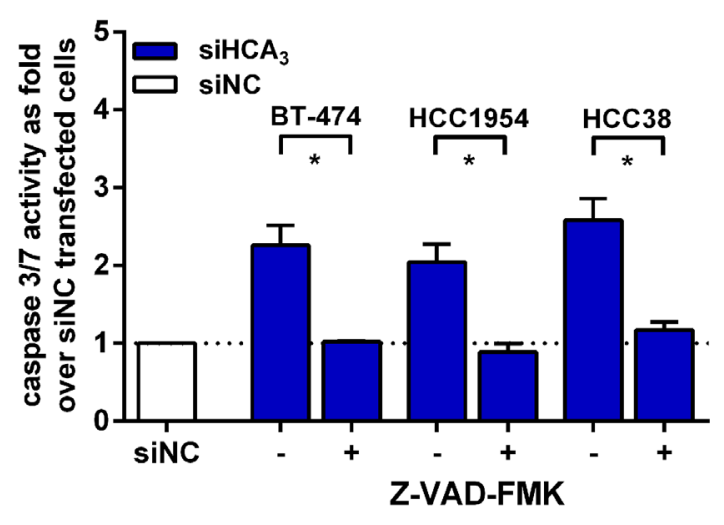

Figure 5: Knock-down of $\mathrm{HCA}_{1}$ and $\mathrm{HCA}_{3}$ induces apoptosis in breast cancer cell lines through caspase 3/7 activation that is diminished with the pan-caspase inhibitor Z-VAD-FMK. (A) Caspase 3/7 activity in siHCA, versus siNC transfected BT-474, HCC1954 and HCC38 cells. (B) Z-VAD-FMK blocks siHCA 1 induced apoptosis in HCC1954 and HCC38 cells. (C) siHCA transfection induces caspase 3/7 activity in all three breast cancer cell lines. (D) siHCA induced caspase 3/7 activity is diminished in the presence of $30 \mu \mathrm{M}$ Z-VAD-FMK (24h after transfection: BT-474, HCC38; 48h post-transfection: HCC1954). All data is shown as mean \pm SEM of three independent experiments carried out in triplicates. $\mathrm{p}$-values were determined using a two-tailed unpaired $\mathrm{t}$-test. * $\mathrm{P} \leq 0.05$; ** $\mathrm{P} \leq 0.01 ; * * * \mathrm{P} \leq 0.001$. 
Knock-down of $\mathrm{HCA}_{1}$ and $\mathrm{HCA}_{3}$ induces apoptosis in breast cancer cell lines through caspase 3/7 activation that is diminished in the presence of the pan-caspase inhibitor Z-VADFMK

Subsequently, we analyzed whether the observed siHCA ${ }_{1}^{-}$and siHCA $_{3}$-induced loss in breast cancer viability was due to apoptosis. Therefore, we measured caspase $3 / 7$ activity $24 \mathrm{~h}$ and $48 \mathrm{~h}$ after siHCA, or siHCA transfection in all three breast cancer cell lines. Increased caspase $3 / 7$ activity was detectable in $\mathrm{siHCA}_{1}$ transfected HCC1954 cells after 48h and in HCC38 cells after 24h and $48 \mathrm{~h}$ (Fig $5 \mathrm{~A}$ ). In the presence of $30 \mu \mathrm{M}$ of the cellpermeable pan-caspase inhibitor Z-VAD-FMK the signal was completely diminished (Figure 5B). The $\mathrm{HCA}_{3}$ knockdown induced apoptosis in all three breast cancer cell lines, where in the BT- 474 and $\mathrm{HCC} 38$ cells the obtained caspase 3/7 activity was highest $24 \mathrm{~h}$, but in HCC1954 $48 \mathrm{~h}$ after siHCA 3 transfection (Figure 5C). Caspase 3/7 activity could not be detected in $\mathrm{siHCA}_{3}$ transfected breast cancer cells when Z-VAD-FMK was present (Figure 5D).

\section{$\mathrm{HCA}_{3}$ knock-down causes a dysregulation of the lipid/fatty acid metabolism}

We hypothesize that $\mathrm{HCA}_{3}$ is important for controlling the balance of lipid/fatty acid metabolism in breast cancer cells. To test our hypothesis, we used LiquidChromatography Mass Spectrometry (LC-MS) to analyze compounds related to lipid/fatty acid metabolism in the medium of siHCA ${ }_{3}$ versus siNC transfected BT- 474 cells (Table S3).

The compound quantity measured as the chromatographic peak height, which is proportional to the metabolite concentration (Table S3), and the cell viability, were determined (Figure S6C). BT-474 cells with only a $30 \%$ reduced $\mathrm{HCA}_{3}$ mRNA level (Figure S6E) and approximately a $25 \%$ decreased viability (Figure S6C), take up significantly more lysophosphatidylcholines, reflecting a higher metabolic demand for lipids (Table S3). Moreover, higher levels of $\mathrm{C}_{10}-\mathrm{C}_{12}-$ and $\mathrm{C}_{14}$-carnitine were detected in the medium of $\mathrm{siHCA}_{3}$ transfected BT-474 cells whereas the short-chain carnitines were unaffected (Figure 6A, Table S3). Furthermore, FAO intermediates such as $3 \mathrm{HO}, 3$-hydroxydecanoate and 3-hydroxydodecanoate as well as 3-oxodocanoate and 3-oxotetradecanoate are liberated to a higher extent from BT-474 with knocked-down $\mathrm{HCA}_{3}$ (Table S3). These metabolites were not detectable in the medium alone, thus leading us to the assumption that they are exclusively produced by metabolically active, viable cells. We normalized the obtained metabolite data for these compounds (Table S3) to the cell viability data determined in parallel (Figure S6C), resulting in a metabolite concentration produced per metabolically active cell (Figure 6A). Similarly, because of their lower detection in the medium alone, we proceeded with the $\mathrm{C}_{10}$, $\mathrm{C}_{12}-$ and $\mathrm{C}_{14}$-carnitines after subtraction of the relative quantity of these carnitines detected in medium alone from the raw data counts (Figure 6A). This data revealed a highly increased, siHCA $_{3}$ concentration-dependent production/release of FAO intermediates and carnitines per viable cell (Figure 6A).

\section{Administration of etomoxir or perhexiline, both inhibitors of FAO, protect BT-474 and HCC1954 cells from siHCA $A_{3}$ induced loss in viability in cells}

To further analyze the role of FAO in relation to $\mathrm{HCA}_{3}$, we tested whether inhibitors of FAO could rescue the siHCA 3 -induced loss of viability in BT-474 and HCC1954. In the presence of etomoxir or perhexiline, both O-carnitine palmitoyltransferase (CPT) inhibitors, no siHCA -induced loss of viability could be observed in BT-474 and HCC1954 cells $24 \mathrm{~h}$ and $48 \mathrm{~h}$ after transfection, respectively (Figure 6B, 6C).

\section{DISCUSSION}

Cancer cell metabolism has gained increasingly attention as being a target for therapeutic intervention, with numerous studies contributing to our understanding of metabolic changes in tumor cells [1-5]. Enzymes involved in central metabolic pathways that are specifically up-regulated in cancer, have come into focus as targets for the development of chemotherapeutic drugs [3-5]. The main difficulty encountered is the fact that most of the central metabolic enzymes are also essential for normal proliferating cells. Consequently, drugs acting upon metabolic enzymes are likely to exhibit unwanted side-effects in normal tissue. In the present study, we show that cancer metabolism can be targeted through the metabolite-sensing HCAs. HCAs belong to the GPCR family, which constitutes a major pharmaceutical target with more than $40 \%$ of all currently available drugs acting through them $[6,7]$. One advantage of targeting cancer metabolism through the transmembrane-spanning GPCRs is that drug-delivery through the membrane to the interior of a cell becomes unnecessary.

In our study, we demonstrate that HCAs are expressed in breast cancer patient tissue, primary breast cancer patient cells and three different breast cancer cell lines (Figure 2). Very recently, $\mathrm{HCA}_{1}$ expression has been demonstrated in several cancer cell types, including colon, lung and breast [21] which is in line with the $\mathrm{HCA}_{1}$ expression we observe (Figure 2, S1). Here, we show that $\mathrm{HCA}_{1}$ is necessary for survival of the HER2-positive breast cancer cell line HCC1954 and the triple-negative HCC38 cells (Figure 4B). Loss of $\mathrm{HCA}_{1}$ in those breast 
cancer cells leads to a loss in viability through apoptosis (Figure 5A). In mice, $\mathrm{HCA}_{1}$ mediates anti-lipolytic effects in an insulin dependent manner [13] and regulation of the lipogenic/lipolytic balance is essential for HER2 overexpressing cancer cells to ensure rapid proliferation
[5]. Due to a high rate of glycolysis, cancer cells produce high levels of lactate which is exported out of the cell (Figure 1). There, sufficiently high lactate concentrations activate $\mathrm{HCA}_{1}$ which subsequently causes inhibition of lipolysis and FAO and as recently shown an increase
A

extracellular
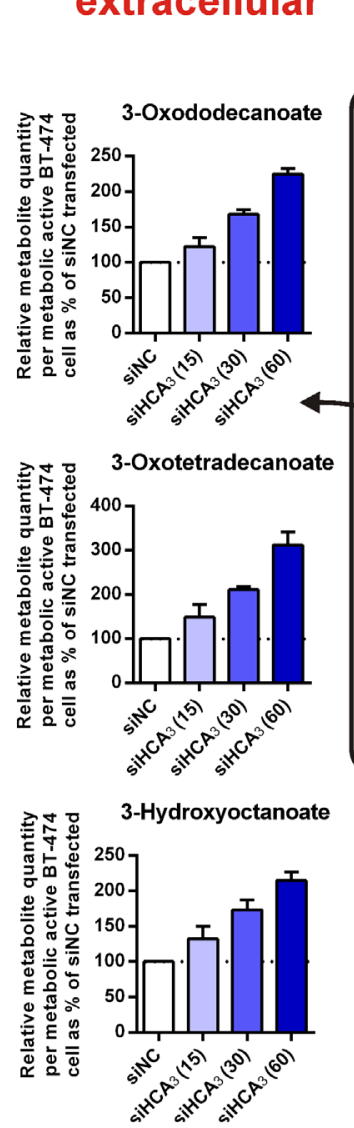

B

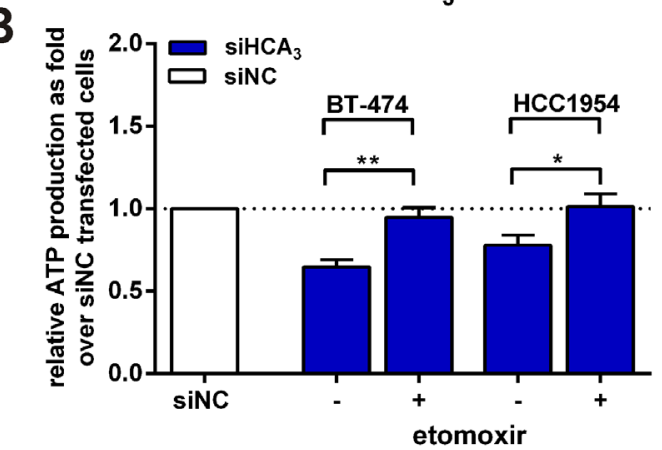

intracellular

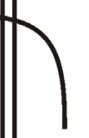

3-O-FAs

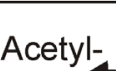

CoA

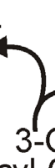

\section{HCA}

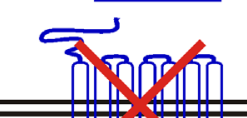

release of $\beta$-oxidation intermediates

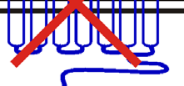

$\beta$-oxidation

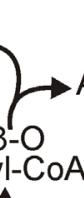

LCFAAcylcarnitines 1

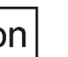

$\checkmark \begin{gathered}3-\mathrm{OH} \\ \text { Acyl-COA }\end{gathered}$

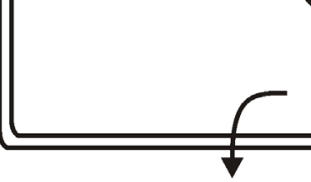

3-OH-FÁs
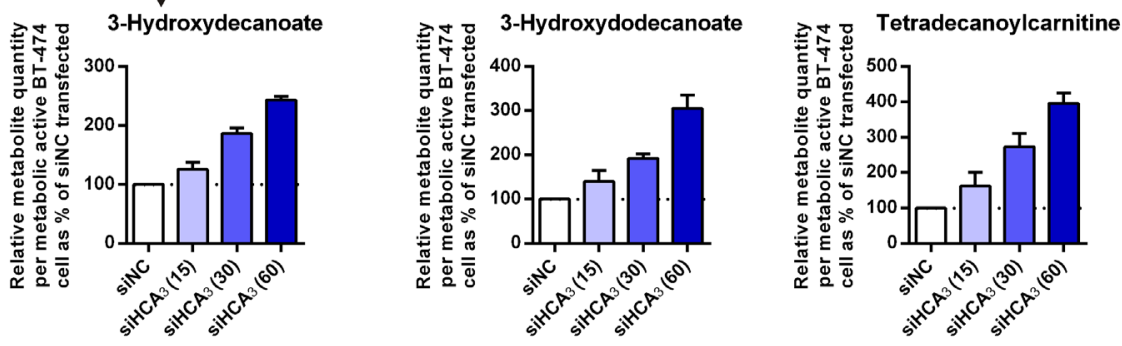

$\operatorname{siHCA}_{3}$

C

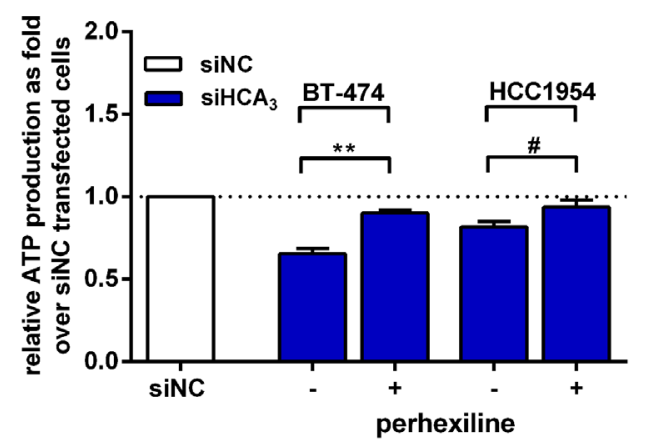

Figure 6: Extracellular concentration of FAO intermediates is increased for BT-474 with knocked-down $\mathrm{HCA}_{3}$ compared to siNC transfected cells and viability is rescued in presence of FAO inhibitors. (A) Metabolites differing in

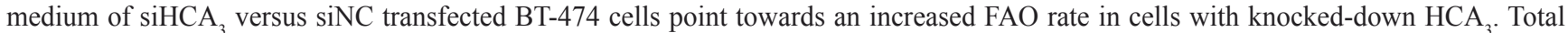
siRNA concentration in each well was $60 \mathrm{nM}$. Concentration of $\mathrm{HCA}_{3}$-specific siRNA is specified on the $\mathrm{x}$-axis inside the parentheses. FAO intermediates were determined using LC-MS $(\mathrm{n}=2)$ and normalized to viable cells (shown in Figure S5C). The data shown reflects relative metabolite quantity produced per metabolically active cells. The value determined for medium of siNC transfected BT-474 was set $100 \%$. Peak height of compounds relative to siNC transfected cells are stated in Table S3. BT-474 and HCC1954 cell viability with knocked-down $\mathrm{HCA}_{3}$ is rescued upon co-administration of (B) $30 \mu \mathrm{M}$ etomoxir $(\mathrm{n}=4)$ or $(\mathrm{C}) 2.5 \mu \mathrm{M}$ perhexiline $(\mathrm{n}=3)$, both inhibitors of FAO. All data is shown as mean \pm SEM. ${ }^{*} \mathrm{P} \leq 0.1 * \mathrm{P} \leq 0.05 ; * * \mathrm{P} \leq 0.01$. 
in mRNA expression levels of genes critical for lactate transport and metabolism [21]. We show, that knockdown of $\mathrm{HCA}_{1}$ is accompanied by an increased mRNA expression of $\mathrm{HCA}_{2}$ and $\mathrm{HCA}_{3}$ (Figure S4A) implying a role for the related HCA family members as secondary metabolic surveillance to monitor cellular metabolic shifts. We suggest that inhibition of FAO/lipolysis through lactate activated $\mathrm{HCA}_{1}$ most likely facilitates a higher rate of fatty acid synthesis and lipogenesis, thereby enabling a higher rate of proliferation.

In contrast, the question arises of why $\mathrm{HCA}_{2}$ knockdown causes an increase in proliferation of breast cancer cells and $\mathrm{HCA}_{2}$ activation suppresses tumor growth as recently shown for colon and mammary tumors [11, 2224]? Assuming a scenario in which cancer cells shunt glucose to anabolic processes rather than oxidizing it for ATP production, the energy demand has to be satisfied through other pathways such as FAO [2]. By increased lipolysis and subsequent FAO, acetyl-CoA is generated which can enter the citric acid cycle [2]. If the level of acetyl CoA exceeds the capacity of the citric acid cycle, ketone bodies such as $3 \mathrm{HB}$ are produced and exported out of the cell where $\mathrm{HCA}_{2}$ is activated and subsequently lipolysis is inhibited (Figure 1). By abrogation of this negative feedback mechanism and in the presence of glucose, cancer cells can maintain a high rate of proliferation that is accompanied by ketone body production, which in turn can again be re-utilized as an energy source $[25,26]$.

Knock-down of $\mathrm{HCA}_{3}$ induced cell death in all three breast cancer cell lines BT-474, HCC1954 and HCC38, accompanied by a remarkable decrease in cell viability (Figure 4D, 5C). $\mathrm{HCA}_{3}$ is a $\mathrm{G} \alpha_{\mathrm{i}}$-coupled receptor that is activated by $3 \mathrm{HO}$ [16]. Micromolar levels of $3 \mathrm{HO}$ can be detected in patients with FAO disorders, including long-chain, medium-chain and short-chain acyl-CoA dehydrogenase defects $[27,28]$ as well as in patients with acute diabetic ketoacidosis and in patients that receive a ketogenic diet [16]. Previous studies indicate that elevated levels of medium chain 3-hydroxy fatty acids, including $3 \mathrm{HO}$ are indicators of and correlate with increased rates of FAO under physiological and pathophysiological conditions [16, 27-30]. Ahmed et al. suggest that $\mathrm{HCA}_{3}$ is a sensor for elevated $3 \mathrm{HO}$ levels which itself is an indicator of high $\beta$-oxidation rates. Activation of $\mathrm{HCA}_{3}$ by $3 \mathrm{HO}$ would inhibit free fatty acid release and thereby lower their availability for FAO and thus constitutes another negative feedback mechanism to control lipolytic activity $[10,16]$.

Our data suggests that this negative feedback mechanism mediated by $\mathrm{HCA}_{3}$ is crucial for BT-474, HCC1954 and HCC38 cell proliferation and survival. We hypothesize that $\mathrm{HCA}_{3}$ has a central role in controlling the balance of lipid/fatty acid metabolism in breast cancer cells. This hypothesis is further supported by our finding of increased levels of $\mathrm{C}_{10}-\mathrm{C}_{12}$ - and $\mathrm{C}_{14}$-carnitine levels as well as FAO intermediates 3HO, 3-hydroxydecanoate, 3-hydroxydodecanoate, 3-oxodocanoate and 3-oxotetradecanoate in the medium of siHCA $_{3}$ transfected BT-474 (Figure 6A, Table S3). Recent evidence shows that $\mathrm{C}_{10}$-carnitine originates from peroxisomal $\mathrm{FAO}$, potentially a compensatory mechanism to metabolize medium- and long-chain fatty acids in cases of mitochondrial FAO overload [31]. Moreover, the extracellular increase of 3-hydroxy- and 3-oxo-FAO intermediates reflects a higher intracellular rate of FAO and especially the extracellular increase of $3 \mathrm{HO}$ upon $\mathrm{HCA}_{3}$ knock-down strongly supports a role for $\mathrm{HCA}_{3}$ in a negative feedback mechanism controlling the FAO rate in BT-474 cells. Further, we show that BT-474 and HCC1954 cell survival with knocked-down HCA3 is rescued in the presence of FAO inhibitors (Figure 6B, 6C) providing further evidence for a critical role of $\mathrm{HCA}_{3}$ in controlling the $\mathrm{FAO}$ rates in breast cancer cells. In summary, the obtained metabolite data points towards an uncontrolled up-regulated FAO in cells with knocked-down $\mathrm{HCA}_{3}$ as the cause for the induced cell death (Figure 4D, 5C, 6A).

We provide evidence that HCAs are important for breast cancer cells to balance their lipid/fatty acid metabolism. Further, we show that cancer cell metabolism can be targeted through GPCRs, thus bypassing direct targeting of intracellular metabolic enzymes. Agonists and antagonists acting at cancer-specific overexpressed metabolite-sensing GPCRs therefore have potential as anti-cancer drugs by perturbing the control of cancer cell metabolism.

\section{MATERIALS AND METHODS}

\section{Cell lines}

Human breast cancer cell lines BT-474 (ATCC®) HTB-20 ${ }^{\mathrm{TM}}$ ), HCC1954 (ATCC $\AA$ CRL-2338 ${ }^{\mathrm{TM}}$ ) and

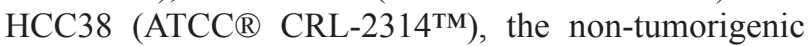
epithelial breast cell line MCF12A (ATCC ${ }^{\circ}$ CRL$10782^{\mathrm{TM}}$ ), the lung cancer cell lines A549 (ATCC® CCL-185 ${ }^{\mathrm{TM}}$ ) and DMS53 (ATCC ${ }$ CRL-2062 ${ }^{\mathrm{TM}}$ ), the leukemia cell lines CCRF-CEM [CCRF CEM] (ATCC® CCL-119 ${ }^{\mathrm{TM}}$ ) (CEM) and HL60 (ATCC ${ }^{\circ}$ CCL-240 ${ }^{\mathrm{TM}}$ ), the prostate cancer cell line LNCaP (ATCC® CRL-1740 ${ }^{\mathrm{TM}}$ ) and the human embryonic kidney cell line HEK293T (ATCC $\AA$ CRL-3216 ${ }^{\mathrm{TM}}$ ) were obtained from American Type Culture Collection and maintained following the recommendations from ATCC.

\section{Primary breast cancer cells}

Primary breast cancer cells originating from three different patients were obtained from Celther Polska Ltd. Cells were cultured in human EpiCult ${ }^{\mathrm{TM}}-\mathrm{C}$ Human 
Medium (StemCell technologies) supplemented with $5 \%$ fetal bovine serum and $0.48 \mu \mathrm{g} / \mathrm{mL}$ hydrocortisone following the recommendations from Celther. The primary human breast cancer cells CLTH/BC-7 were obtained from a 49 year old human invasive ductual breast carcinoma patient. The primary human breast cancer cells CLTH/BC8 originate from 47 year old individual with invasive ductual breast carcinoma and CLTH/BC9 are taken from a 49 year old patient with invasive breast carcinoma (ER (-); PR (-); HER (+)) All primary cells are positive for MGB-1 which is specific for breast cells, they express an isoform 7 of MUC-1 which is specific for tumor cells.

\section{cAMP assay}

Two days prior determination of agonist-mediated inhibition of forskolin-induced cAMP production, 20.000 $\mathrm{c} / \mathrm{w}$ BT-474 were seeded in 96w plates in RPMI 1640 containing 10\% FBS, $4.5 \mathrm{~g} / 1$ glucose, $2 \mathrm{mM}$ glutamine, $5 \mathrm{mM}$ HEPES and $1 \mathrm{mM}$ sodium pyruvate. One day after seeding, medium was replaced with serum free RPMI1640 with or without $100 \mathrm{ng} / \mu \mathrm{L}$ pertussis toxin and incubated for another $24 \mathrm{~h}$, before stimulation with various agonist concentrations (carried out in triplicates) was performed in presence of $10 \mu \mathrm{M}$ forskolin and $1 \mathrm{mM}$ 3-isobutyl-1-methylxanthine (IBMX). Reactions were stopped by aspiration of media on ice and cells lysis with $20 \mu \mathrm{l}$ of lysis buffer containing $1 \mathrm{mM}$ IBMX. The cAMP content of cell extracts was determined using the AlphaScreen ${ }^{\circledR}$ cAMP Assay Kit (Perkin Elmer) according to the manufacturers' protocol. From each 96w $5 \mu \mathrm{l}$ of lysate were transferred to a $384 \mathrm{w}$ plate. Acceptor beads (in stimulation buffer without IBMX) and donor beads were added according to the instructions given by the manufacturer.

\section{ELISA}

An indirect cellular ELISA was used to estimate cell surface expression of N-terminal HA-tagged receptor constructs. Briefly, HEK293T cells were seeded into polyL-lysine coated 48 -well plates ( $8 \times 10^{4}$ cells per well) and transfected the following day with $0.2 \mu \mathrm{g}$ DNA, $80 \mathrm{nM}$ siRNA and $0.5 \mu$ l Lipofectamine $^{\mathrm{TM}} 2000$ per well according to the manufacturers' protocol. $24 \mathrm{~h}$ hours after transfection cells were fixed with formaldehyde, without disrupting the cell membrane and incubated in blocking solution (DMEM with $10 \% \mathrm{FBS}$ ) for $1 \mathrm{~h}$ at $37^{\circ} \mathrm{C}$. Cells were then incubated with anti-HA-peroxidase-labelled high affinity rat monoclonal antibody (3F10, Roche Molecular Biochemicals, Mannheim, Germany). After removal of excess unbound antibody by extensive washing, $\mathrm{H}_{2} \mathrm{O}_{2}$ and o-phenylenediamine $(2.5 \mathrm{mM}$ each in $0.1 \mathrm{M}$ phosphate-citrate buffer, $\mathrm{pH}$ 5.0) were added to serve as substrate and chromogen, respectively. After
15 min the enzyme reaction was stopped by adding $1 \mathrm{M} \mathrm{H}_{2} \mathrm{SO}_{4}$ containing $0.05 \mathrm{M} \mathrm{Na} 2 \mathrm{SO} 4$, and colour development was measured bichromatically at 492 and $620 \mathrm{~nm}$ using an ELISA reader (TECAN Sunrise plate reader).

\section{siRNA and plasmid transfection}

HCAR1 (ID 27198), HCAR2 (ID 338442), HCAR3 (ID 8843) and Universal scrambled negative control trilencer-27 human siRNA were purchased from OriGene (Table S2). One day prior transfection, $15.000 \mathrm{c} / \mathrm{w}$ BT-474, $7.500 \mathrm{c} / \mathrm{w}$ HCC1954 and $15.000 \mathrm{c} / \mathrm{w}$ HCC38 were seeded in 96w plates in RPMI1640 (HyClone) containing 10\% FBS (Sigma Aldrich), $4.5 \mathrm{~g} / 1$ glucose, 2 $\mathrm{mM}$ glutamine, $5 \mathrm{mM}$ HEPES, $1 \mathrm{mM}$ sodium pyruvate (Life Technologies). Just before transfection medium was changed to RPMI1640 containing 2.5\% FBS, $2 \mathrm{~g} / 1$ glucose and $2 \mathrm{mM}$ glutamine. $24 \mathrm{~h}$ before transfection $15.000 \mathrm{c} / \mathrm{w}$ MCF12A were seeded in 96w plate in a 1:1 mixture of Dulbecco's modified Eagle's medium (DMEM) and Ham's F12 medium (Life Technologies) supplemented with $5 \%$ horse serum (Sigma Aldrich), $20 \mathrm{ng} / \mathrm{ml}$ human epidermal growth factor (Sigma Aldrich), $100 \mathrm{ng} / \mathrm{ml}$ cholera toxin (Sigma Aldrich), $0.01 \mathrm{mg} / \mathrm{ml}$ bovine insulin (Sigma Aldrich) and $500 \mathrm{ng} / \mathrm{ml}$ hydrocortisone (Sigma Aldrich). Prior transfection medium was replaced with fresh medium. $5.000 \mathrm{c} / \mathrm{w}$ HEK293T cells were seeded in a 96w plate in DMEM (Sigma Aldrich) supplemented with $10 \%$ FBS and $24 \mathrm{~h}$ later, before siRNA transfection medium was changed to DMEM supplemented with $2.5 \%$ FBS.

Subsequently, cells were transfected using SAINTRED (Synvolux Therapeutics) or SAINT-MIX (Synvolux Therapeutics) for siRNA or plasmid transfection following manufacturer's instructions, respectively. BT-474, MCF12A and HEK293T cells were transfected with a final concentration of $60 \mathrm{nM}$ or $80 \mathrm{ng}$ plasmid per well, using $1.2 \mu 1$ SAINT-RED or SAINT-MIX, respectively. HCC1954 cells were transfected with a final concentration of $40 \mathrm{nM}$ siRNA or $40 \mathrm{ng}$ plasmid per well, using $0.8 \mu \mathrm{l}$ SAINT-RED or SAINT-MIX, respectively.

\section{Generation of human $\mathrm{HCA}_{1}, \mathrm{HCA}_{2}$ and $\mathrm{HCA}_{3}$ constructs}

Primer pairs (Table S4) were used to amplify human HCAR1 (NM_032554.3), human HCAR2 (NM_177551.3) and human HCAR3 (NM_006018.2) from genomic DNA. Genomic DNA samples were prepared from HCC1954 cells using DNeasy®Blood\&Tissue Kit (Qiagen). The PCR reaction $(50 \mu \mathrm{l})$ contained genomic DNA (100 ng) with primers (400 $\mathrm{nM}$ each), ThermoPol reaction buffer (1x), dNTP (125 $\mu \mathrm{M}$, each) and Taq- and Pfu-polymerase (0.5 U each, NEB). The reactions were initiated with a 
denaturation at $95^{\circ} \mathrm{C}$ for $2 \mathrm{~min}$, followed by 30 cycles of denaturation at $95^{\circ} \mathrm{C}$ for $30 \mathrm{~s}$, annealing at $58^{\circ} \mathrm{C}$ for $30 \mathrm{~s}$ and elongation at $72^{\circ} \mathrm{C}$ for $1 \mathrm{~min}$. A final extension step was performed at $72^{\circ} \mathrm{C}$ for $10 \mathrm{~min}$. Specific PCR products were directly sub-cloned into the pCR2.1-TOPO vector (Invitrogen) for sequencing. Sequencing reactions were performed with a dye-terminator cycle sequencing kit and applied on an ABI 3700 automated sequencer (Applied Biosystems).

The full length human HCAR1, human HCAR2 and human HCAR3 with an N-terminal hemagglutinin (HA) epitope (YPYDVPDYA) and a C-terminal FLAGtag (DYKDDDDK) were inserted into the mammalian expression vector pcDNA3.1(-) (Invitrogen).

\section{Cell viability, apoptosis}

ATPlite $^{\mathrm{TM}}$ (PerkinElmer) was used to determine cell viability according to manufacturers' instructions. $30 \mu \mathrm{M}$ etomoxir or $2.5 \mu \mathrm{M}$ perhexiline were added $6 \mathrm{~h}$ after transfection and viability was measured 24h (BT474 ) or $48 \mathrm{~h}$ (HCC1954) after transfection (Figure $6 \mathrm{~B}, 6 \mathrm{C})$. Crystal violet staining was used to observe cell viability with microscopy (Figure 4A). 48h after siRNA transfection medium was completely removed from all wells and cells were incubated 10 min with a $1 \%$ crystal violet solution in $3.6 \%$ paraformaldehyde, $1 \% \mathrm{MeOH}$ and 20\% EtOH. Subsequently, cells were washed three times with water and microscoped. Caspase-Glo® 3/7 Assay (Promega) was used to measure apoptosis. Z-VAD-FMK (Promega) was added to a final concentration of $30 \mu \mathrm{M} 30 \mathrm{~min}$ before siRNA transfection and apoptosis was measured 24h (BT-474, HCC38) or 48h (HCC1954) after transfection.

\section{RNA preparation, reverse transcription and quantitative real-time PCR}

Here, we provide a detailed protocol description according to the MIQE guidelines [32] regarding each experimental step as well as choice of reference genes, data analyses and primers used.

To determine basal expression of $\mathrm{HCA}_{1}, \mathrm{HCA}_{2}$ and $\mathrm{HCA}_{3}, \mathrm{BT}-474(500.000 \mathrm{c}), \mathrm{HCC} 1954$ (150.000 c), $\mathrm{HCC} 38$ (500.000 c), MCF12A (500.000 c), A549 (500.000 c), DMS53 (1.000.000 c), CEM (1.000.000 c) HL60 (1.000.000 c), LNCaP (1.000.000 c) and primary breast cancer $(2.000 .000 \mathrm{c})$ cells were seeded in a $6 \mathrm{w}$ plate and cultured for $48 \mathrm{~h}$ in their respective medium (as recommended from ATCC) before harvested for RNA preparation. To determine siRNA knock-down efficiency BT-474 and HCC1954 cells were siRNA transfected in 96w plates as stated before in RPMI1640 containing 2.5\% FBS, 2 g/l glucose and $2 \mathrm{mM}$ glutamine (corresponding qPCR data in Figure S4) or RPMI1640 containing 10\%
FBS, $4.5 \mathrm{~g} / 1$ glucose, $2 \mathrm{mM}$ glutamine, $5 \mathrm{mM}$ HEPES and $1 \mathrm{mM}$ sodium pyruvate with medium change before and $24 \mathrm{~h}$ after transfection (corresponding qPCR data in Figure S5E-F), and cells of four wells were harvested $48 \mathrm{~h}$ after transfection. Total RNA isolation was performed using RNeasy® Mini Kit (Qiagen) following manufacturers' instructions. RNA concentration was determined with a NanoDrop ${ }^{\circledR}$ ND-1000 in TE (pH 8), OD A260/A280 ratios were 1.9-2.0. Prior reverse transcription, $1 \mu \mathrm{g}$ RNA (determination of basal HCA expression in cell lines and primary breast cancer cells) or 100-300 ng (determination of knock-down efficiency) were treated with $1 \mu$ l DnaseI (NEB) in a total reaction volume of $10 \mu \mathrm{l}$ for $10 \mathrm{~min}$ at $37^{\circ} \mathrm{C}$. Reaction was stopped by addition of $1 \mu 150 \mathrm{mM}$ EDTA and heat inactivation for $10 \mathrm{~min}$ at $75^{\circ} \mathrm{C}$. Directly thereafter, RNA was reverse transcribed using iScript ${ }^{\mathrm{TM}}$ cDNA Synthesis Kit (Bio-Rad) following the manufacturer's instructions. TissueScan ${ }^{\mathrm{TM}}$ Cancer Survey cDNA qPCR Array - I (CSRT501) from OriGene Technologies is a panel of normalized cDNA from multiple cancer tissues. A report, including information about disease state for each sample as well as an electropherogramm indicating RNA quality and bioanalyzer ratio is provided (CSRT101 - http://www. origene.com/qPCR/Tissue-qPCR-Arrays.aspx). OriGene received high quality total RNA from Cytomyx and generated first-strand cDNA using an oligo-dT primer. The average amount of cDNA is 2-3 ng per well but can vary due to normalization based on $\beta$-actin.

The qPCR setup was as follows: each reaction $(20 \mu \mathrm{l})$ contained cDNA (10-20 ng for determination of basal expression levels of HCA in cell lines and primary breast cancer cells; 2-5 ng for determination of knock-down efficiency after siRNA transfection), primers (500 nM each in final reaction) and $10 \mu 1$ iTaq $^{\text {TM }}$ Universal SYBR ${ }^{\circledR}$ Green Supermix (Bio-Rad). The following thermal cycling protocol was used: polymerase activation at $95^{\circ} \mathrm{C}$ for $30 \mathrm{~s}$, followed by 40 cycles of $15 \mathrm{~s}$ of denaturation at $95^{\circ} \mathrm{C}$ and $30 \mathrm{~s}$ of monitored annealing/extension at $60^{\circ} \mathrm{C}$. Subsequently, melt curves were recorded $\left(55^{\circ} \mathrm{C}-\right.$ $94.5^{\circ} \mathrm{C}, 0.5^{\circ} \mathrm{C}$ increment, $\left.10 \mathrm{~s} / \mathrm{step}\right)$. Real-time PCR and data collection (analysis mode: PCR baseline subtracted, baseline was manually set to 500 for cancer panel data and 300 for all other data) were performed on Bio-Rad $\mathrm{RiQ}^{\mathrm{TM}} 5$ Real-Time PCR Detection System.

If not specified differently, primers (stated in Table S5) were designed using Primer-Blast (http://www.ncbi. nlm.nih.gov/tools/primer-blast/) [33], product size: 80$200 \mathrm{bp}, \mathrm{Tm} 59^{\circ} \mathrm{C}-61^{\circ} \mathrm{C}, \max \mathrm{T}_{\mathrm{m}}$ difference $1^{\circ} \mathrm{C}$ and high primer specificity stringency settings. Primers with highest specificity and lowest values for 3'- and selfcomplementarity were chosen and ordered from Life Technologies. With each primer pair specified in Table S5 and Table S6, melt curves after the qPCR run showed as one single sharp peak. Agarose gel analyses revealed only one band of correct size. Primer efficiency (stated 
in Table S5) was determined using $1 / 5$ dilutions $(4 \mathrm{x})$ of pooled cDNA ( $20 \mathrm{ng})$. Data was analyzed using linear regression analysis implemented in GraphPad Prism version 6.03 for Windows (GraphPad Software). Raw C values collected from the thermocycler were imported and analyzed using the Gene Expression Analysis for iCycler $\mathrm{iQ}{ }^{\circledR}$ Real-time PCR Detection System version 1.10 (2004) Excel Spreadsheet that was downloaded from http://www. bio-rad.com/ and is derived from algorithms outlined by Vandesompele et al. [34]. Primer efficiency was set $100 \%$, thus using the $\Delta \Delta \mathrm{C}_{\mathrm{q}}$ method to analyze the data. TissueScan ${ }^{\mathrm{TM}}$ Cancer Survey cDNA qPCR Array data was normalized to endogenous control/reference gene $\beta$-actin $(n=2)$ as recommended from OriGene after consultation of product support, using the primers provided (stated in Table S5). qPCR for each HCA was run in duplicate using commercially available primer (SABiosciences, information provided stated in Table S6) for one replicate and self-designed primer pairs for the second replicate (primer No. 1-6 stated in Table S5). Basal expression of $\mathrm{HCA}_{1}, \mathrm{HCA}_{2}$ and $\mathrm{HCA}_{3}$ was normalized to reference gene RPS18. In total, 5 reference genes (RPS18, ACTB, GAPDH, RPL13A, RPLO) were tested and Normfinder [35] was used to identify the most stably expressed gene (stability values: RPS18: 0.104, ACTB: 0.375, GAPDH: 0.174, RPL13A: 0.312, RPLO: 0.174). All qPCR data from knock-down experiments was normalized to RPS18 and ACTB. 5 reference genes were tested for knockdown in HCC1954 and again Normfinder [35] was used to determine stability values (RPS18: 0.050, RPL13A: 0.050, ACTB: 0.060, HSC70: 0.377, H2ai: 0.480). For all experiments indicated $\mathrm{n}$ reflect biological replicates, that were reverse-transcribed and qPCR was run in duplicates.

\section{Liquid Chromatography Mass Spectrometry (LC- MS) measurement}

One day prior transfection, 15.000 BT-474 cells per well were seeded in 96w plates in RPMI1640 containing 10\% FBS, $4.5 \mathrm{~g} / 1$ glucose, $2 \mathrm{mM}$ glutamine, $5 \mathrm{mM}$ HEPES, $1 \mathrm{mM}$ sodium pyruvate. Medium was changed prior and $24 \mathrm{~h}$ after transfection and cells were transfected as described above. $48 \mathrm{~h}$ after transfection the $96 \mathrm{w}$ plates were briefly centrifuged and $80 \mu \mathrm{l}$ medium were directly added to an Eppendorf tube containing $320 \mu \mathrm{l}$ ice-cold $\mathrm{MeOH}$. Tubes were incubated $20 \mathrm{~min}$ at $-20^{\circ} \mathrm{C}, 10 \mathrm{~min}$ centrifuged $(14.000 \mathrm{rpm})$ at $4^{\circ} \mathrm{C}$ and supernatant was transferred to LC-MS glass vials, dried down in a speed vacuum concentrator and stored at $-20^{\circ} \mathrm{C}$ until analysis. Samples were dissolved in $20 \mu \mathrm{L} 50: 50 \mathrm{MeOH}: \mathrm{H}_{2} \mathrm{O}$ of which $2 \mu \mathrm{L}$ were injected into the Agilent $1290 \mathrm{LC}$-system connected to a 6550 Agilent Q-TOF mass spectrometer and an electrospray ionization (ESI) source was used. Data was collected in positive and negative ionization mode. ESI (Agilent Jetstream) settings were as follows; gas temperature $300^{\circ} \mathrm{C}$, gas flow $8 \mathrm{l} / \mathrm{min}$, nebulizer pressure 40 psi, sheet gas temperature $350^{\circ} \mathrm{C}$, sheet gas flow 11 , Vcap 4000, fragmentor 100, Skimmer1 45 and OctapoleRFPeak 750. Medium metabolites were separated using reverse phase chromatography (Kinetex C18, $100 \mathrm{~mm} * 2.1 \mathrm{~mm}$, $2.6 \mu \mathrm{M} 100 \AA$, Phenomenex). For reversed phase elution, solvents were prepared as follows (A) $\mathrm{H}_{2} \mathrm{O}, 0.1 \%$ formic acid (B) 75:25 acetonitrile: isopropanol, $0.1 \%$ formic acid. All solvents were of HPLC grade. Linear gradients were devised as follows for reversed phase separation $(0.5 \mathrm{~mL} /$ minute) minute $0: 5 \% \mathrm{~B}$, minute $8: 95 \% \mathrm{~B}$, minute 10 : $95 \% \mathrm{~B}$, minute $10.2: 5 \% \mathrm{~B}$, minute $12: 5 \% \mathrm{~B}$. Data was analyzed using Mass Hunter Qual (Agilent) using the "find by formula" function with a match tolerance for masses of $10 \mathrm{ppm}$ and for retention times of $0.35 \mathrm{~min}$. The list of all compounds analyzed, including sum formulas, monoisotopic masses and normalized fold changes can be found in Table S3. Most of the metabolites were identified using synthetic standards obtained from Sigma Aldrich, Santa Cruz Biotechnology or Cayman Chemical comparing accurate mass, retention time and in some cases MS/MS spectra.

\section{Statistical analyses and graphs}

All statistical analyses and determination of concentration-response curves of agonists were performed and graphs generated using GraphPad Prism version 6.03 for Windows (GraphPad Software). All indicated n reflect the number of biological replicates.

\section{ACKNOWLEDGEMENTS}

We thank Siv Sääf and Petra Krumbholz for technical assistance and Thomas Moritz as well as Anetta Svitorka Härtlova for critical reading of the manuscript. This research is supported by grants from the ErlingPersson family foundation (to Umeå University), Swedish Foundation for Strategic Research (to A.N.), Knut \& Alice Wallenberg Foundation (to Swedish Metabolomics Centre) and Jane and Dan Olsson Foundations (to A.N.). Umeå University and Swedish University of Agricultural Science are acknowledged for support to the Swedish Metabolomics Centre.

\section{CONFLICT OF INTEREST}

The authors declare that they have no competing financial interests.

\section{REFERENCES}

1. Vander Heiden MG, Cantley LC and Thompson CB. Understanding the Warburg effect: the metabolic requirements of cell proliferation. Science. 2009; 
324(5930):1029-1033.

2. Carracedo A, Cantley LC and Pandolfi PP. Cancer metabolism: fatty acid oxidation in the limelight. Nature reviews Cancer. 2013; 13(4):227-232.

3. Zhao Y, Butler EB and Tan M. Targeting cellular metabolism to improve cancer therapeutics. Cell death \& disease. 2013; 4:e532.

4. Vander Heiden MG. Targeting cancer metabolism: a therapeutic window opens. Nature reviews Drug discovery. 2011; 10(9):671-684.

5. Menendez JA. Fine-tuning the lipogenic/lipolytic balance to optimize the metabolic requirements of cancer cell growth: molecular mechanisms and therapeutic perspectives. Biochimica et biophysica acta. 2010; 1801(3):381-391.

6. Drews J. Drug discovery: A historical perspective. Science. 2000; 287(5460):1960-1964.

7. Lundstrom K. An overview on GPCRs and drug discovery: structure-based drug design and structural biology on GPCRs. Methods in molecular biology. 2009; 552:51-66.

8. Blad CC, Tang C and Offermanns S. G protein-coupled receptors for energy metabolites as new therapeutic targets. Nature reviews Drug discovery. 2012; 11(8):603-619.

9. Offermanns S. Free fatty acid (FFA) and hydroxy carboxylic acid (HCA) receptors. Annual review of pharmacology and toxicology. 2014; 54:407-434.

10. Offermanns S, Colletti SL, Lovenberg TW, Semple G, Wise A and AP IJ. International Union of Basic and Clinical Pharmacology. LXXXII: Nomenclature and Classification of Hydroxy-carboxylic Acid Receptors (GPR81, GPR109A, and GPR109B). Pharmacological reviews. 2011; 63(2):269290.

11. Santolla MF, De Francesco EM, Lappano R, Rosano C, Abonante $\mathrm{S}$ and Maggiolini M. Niacin activates the $\mathrm{G}$ protein estrogen receptor (GPER)-mediated signalling. Cellular signalling. 2014; 26(7):1466-1475.

12. Liu C, Wu J, Zhu J, Kuei C, Yu J, Shelton J, Sutton SW, Li X, Yun SJ, Mirzadegan T, Mazur C, Kamme F and Lovenberg TW. Lactate inhibits lipolysis in fat cells through activation of an orphan G-protein-coupled receptor, GPR81. The Journal of biological chemistry. 2009; 284(5):28112822.

13. Ahmed K, Tunaru S, Tang C, Muller M, Gille A, Sassmann A, Hanson J and Offermanns S. An autocrine lactate loop mediates insulin-dependent inhibition of lipolysis through GPR81. Cell metabolism. 2010; 11(4):311-319.

14. Cai TQ, Ren N, Jin L, Cheng K, Kash S, Chen R, Wright SD, Taggart AK and Waters MG. Role of GPR81 in lactatemediated reduction of adipose lipolysis. Biochemical and biophysical research communications. 2008; 377(3):987991.

15. Taggart AK, Kero J, Gan X, Cai TQ, Cheng K, Ippolito M, Ren N, Kaplan R, Wu K, Wu TJ, Jin L, Liaw C, Chen R, Richman J, Connolly D, Offermanns S, et al. (D)beta-Hydroxybutyrate inhibits adipocyte lipolysis via the nicotinic acid receptor PUMA-G. The Journal of biological chemistry. 2005; 280(29):26649-26652.

16. Ahmed K, Tunaru S, Langhans CD, Hanson J, Michalski CW, Kolker S, Jones PM, Okun JG and Offermanns S. Deorphanization of GPR109B as a receptor for the betaoxidation intermediate $3-\mathrm{OH}$-octanoic acid and its role in the regulation of lipolysis. The Journal of biological chemistry. 2009; 284(33):21928-21933.

17. Liu C, Kuei C, Zhu J, Yu J, Zhang L, Shih A, Mirzadegan T, Shelton J, Sutton S, Connelly MA, Lee G, Carruthers $\mathrm{N}, \mathrm{Wu} \mathrm{J}$ and Lovenberg TW. 3,5-Dihydroxybenzoic acid, a specific agonist for hydroxycarboxylic acid 1, inhibits lipolysis in adipocytes. The Journal of pharmacology and experimental therapeutics. 2012; 341(3):794-801.

18. Hanson J, Gille A, Zwykiel S, Lukasova M, Clausen BE, Ahmed K, Tunaru S, Wirth A and Offermanns S. Nicotinic acid- and monomethyl fumarate-induced flushing involves GPR109A expressed by keratinocytes and COX2-dependent prostanoid formation in mice. The Journal of clinical investigation. 2010; 120(8):2910-2919.

19. Semple G, Skinner PJ, Cherrier MC, Webb PJ, Sage CR, Tamura SY, Chen R, Richman JG and Connolly DT. 1-Alkyl-benzotriazole-5-carboxylic acids are highly selective agonists of the human orphan G-protein-coupled receptor GPR109b. Journal of medicinal chemistry. 2006; 49(4):1227-1230.

20. Zhou Q, Li G, Deng XY, He XB, Chen LJ, Wu C, Shi Y, Wu KP, Mei LJ, Lu JX and Zhou NM. Activated human hydroxy-carboxylic acid receptor-3 signals to MAP kinase cascades via the PLC-dependent PKC and MMP-mediated EGFR pathways. British journal of pharmacology. 2012; 166(6):1756-1773.

21. Roland CL, Arumugam T, Deng D, Liu SH, Philip B, Gomez S, Burns WR, Ramachandran V, Wang H, CruzMonserrate $\mathrm{Z}$ and Logsdon CD. Cell surface lactate receptor GPR81 is crucial for cancer cell survival. Cancer research. 2014; 74(18):5301-5310.

22. Elangovan S, Pathania R, Ramachandran S, Ananth S, Padia RN, Lan L, Singh N, Martin PM, Hawthorn L, Prasad PD, Ganapathy V and Thangaraju M. The niacin/butyrate receptor GPR109A suppresses mammary tumorigenesis by inhibiting cell survival. Cancer research. 2014; 74(4):11661178.

23. Thangaraju $\mathrm{M}$, Cresci GA, Liu $\mathrm{K}$, Ananth $\mathrm{S}$, Gnanaprakasam JP, Browning DD, Mellinger JD, Smith SB, Digby GJ, Lambert NA, Prasad PD and Ganapathy V. GPR109A is a G-protein-coupled receptor for the bacterial fermentation product butyrate and functions as a tumor suppressor in colon. Cancer research. 2009; 69(7):28262832.

24. Singh N, Gurav A, Sivaprakasam S, Brady E, Padia R, Shi H, Thangaraju M, Prasad PD, Manicassamy S, Munn DH, Lee JR, Offermanns S and Ganapathy V. Activation of Gpr109a, Receptor for Niacin and the Commensal Metabolite Butyrate, Suppresses Colonic Inflammation and 
Carcinogenesis. Immunity. 2014; 40(1):128-139.

25. Martinez-Outschoorn UE, Lin Z, Whitaker-Menezes D, Howell A, Sotgia F and Lisanti MP. Ketone body utilization drives tumor growth and metastasis. Cell cycle. 2012; 11(21):3964-3971.

26. Kallinowski F, Vaupel P, Runkel S, Berg G, Fortmeyer HP, Baessler KH, Wagner K, Mueller-Klieser W and Walenta S. Glucose uptake, lactate release, ketone body turnover, metabolic micromilieu, and $\mathrm{pH}$ distributions in human breast cancer xenografts in nude rats. Cancer research. 1988; 48 (24 Pt 1):7264-7272.

27. Costa CG, Dorland L, Holwerda U, de Almeida IT, PollThe BT, Jakobs C and Duran M. Simultaneous analysis of plasma free fatty acids and their 3-hydroxy analogs in fatty acid beta-oxidation disorders. Clinical chemistry. 1998; 44(3):463-471.

28. Jones PM, Burlina $\mathrm{AB}$ and Bennett MJ. Quantitative measurement of total and free 3-hydroxy fatty acids in serum or plasma samples: short-chain 3-hydroxy fatty acids are not esterified. Journal of inherited metabolic disease. 2000; 23(7):745-750.

29. Jones PM, Tjoa S, Fennessey PV, Goodman SI and Bennett MJ. Addition of quantitative 3-hydroxy-octadecanoic acid to the stable isotope gas chromatography-mass spectrometry method for measuring 3-hydroxy fatty acids. Clinical chemistry. 2002; 48(1):176-179.

30. Ahmed K, Tunaru S and Offermanns S. GPR109A, GPR109B and GPR81, a family of hydroxy-carboxylic acid receptors. Trends in pharmacological sciences. 2009; 30(11):557-562.

31. Violante S, Ijlst L, Te Brinke H, Koster J, Tavares de Almeida I, Wanders RJ, Ventura FV and Houten SM. Peroxisomes contribute to the acylcarnitine production when the carnitine shuttle is deficient. Biochimica et biophysica acta. 2013; 1831(9):1467-1474.

32. Bustin SA, Benes V, Garson JA, Hellemans J, Huggett J, Kubista M, Mueller R, Nolan T, Pfaffl MW, Shipley GL, Vandesompele J and Wittwer CT. The MIQE guidelines: minimum information for publication of quantitative real-time PCR experiments. Clinical chemistry. 2009; 55(4):611-622.

33. Ye J, Coulouris G, Zaretskaya I, Cutcutache I, Rozen S and Madden TL. Primer-BLAST: a tool to design targetspecific primers for polymerase chain reaction. BMC bioinformatics. 2012; 13:134.

34. Vandesompele J, De Preter K, Pattyn F, Poppe B, Van Roy N, De Paepe A and Speleman F. Accurate normalization of real-time quantitative RT-PCR data by geometric averaging of multiple internal control genes. Genome biology. 2002; 3(7):RESEARCH0034.

35. Andersen CL, Jensen JL and Orntoft TF. Normalization of real-time quantitative reverse transcription-PCR data: a model-based variance estimation approach to identify genes suited for normalization, applied to bladder and colon cancer data sets. Cancer research. 2004; 64(15):5245-5250. 